\title{
PENGARUH KECERDASAN EMOSI, LINGKUNGAN SEKOLAH TERHADAP MOTIVASI BELAJAR DAN DAMPAKNYA TERHADAP PRESTASI BELAJAR SISWA
}

\author{
Fransiscus Amonio Halawa ${ }^{1)}$ \\ Fabianus Fensi ${ }^{2)}$ \\ 1)Mahasiswa S3 PEP, Universitas Universitas Negeri Jakarta \\ 2) IImu Komunikasi/Fakultas IImu Sosial dan Humaniora, Universitas Bunda Mulia
}

Diterima: 31 Juli 2020 / Disetujui: 31 Agustus 2020

\begin{abstract}
This research is to analyze the effect of emotional intelligence, school environment on learning motivation and its impact on student achievement. The research methodology used is quantitative research using survey methods that are intended to provide an explanation. Survey research is research that takes a sample from a population and uses a questionnaire as a primary collection tool. There are 3 variables used, they are independent variable, mediation variable and dependent variable. Emotional intelligence and school environment as independent variables, learning motivation as mediating variables and learning achievement as dependent variables. The study involved as many as 89 students as respondents, the data were analyzed with SmartPLS 3.0. The results showed that emotional intelligence had a positive and significant effect on learning motivation, emotional intelligence had a positive and significant effect on learning achievement, the school environment had a positive and significant effect on learning motivation, the school environment had a positive and significant effect on learning achievement and learning motivation had a positive and significant effect towards learning achievement.
\end{abstract}

Keywords: Emotional intelligence, school environment, learning motivation, learning achievement

\begin{abstract}
ABSTRAK
Penelitian ini untuk menganalisis pengaruh kecerdasan emosi, lingkungan sekolah terhadap motivasi belajar dan dampaknya terhadap prestasi belajar siswa. Metodologi penelitian yang digunakan adalah penelitian kuantitatif dengan menggunakan metode survei yang dimaksudkan untuk memberikan penjelasan. Penelitian survei merupakan penelitian yang mengambil sampel dari suatu populasi dan menggunakan kuesioner sebagai alat pengumpulan yang pokok. Ada 3 variabel yang digunakan yaitu variabel bebas, variabel mediasi dan variabel terikat. Kecerdasan emosi dan lingkungan sekolah sebagai variabel bebas, motivasi belajar sebagai variabel mediasi dan prestasi belajar sebagai variabel terikat. Penelitian melibatkan sebanyak 89 siswa sebagai responden, data dianalisis dengan SmartPLS 3.0. Hasil penelitian menunjukan bahwa kecerdasan emosi berpengaruh positif dan signifikan terhadap motivasi belajar, kecerdasan emosi berpengaruh positif dan signifikan terhadap prestasi belajar, lingkungan sekolah berpengaruh positif dan signifikan terhadap motivasi belajar, lingkungan sekolah berpengaruh positif dan signifikan terhadap prestasi belajar dan motivasi belajar berpengaruh positif dan signifikan terhadap prestasi belajar.
\end{abstract}

Kata kunci : Kecerdasan emosi, lingkungan sekolah, motivasi belajar, Prestasi belajar

Coresponding Author: frans_halawa@yahoo.com 


\section{PENDAHULUAN}

Dunia pendidikan masa kini mengenal tiga kompetensi penting yang harus dimiliki oleh seorang siswa setelah mengalami proses pendidikan yaitu, aspek kognitif (pengetahuan umum), psikomotor (praktek), dan afektif (sikap diri). Selama ini banyak orang yang berpendapat bahwa untuk meraih prestasi belajar yang tinggi diperlukan kecerdasan intelektual (IQ) yang tinggi. Namun, menurut hasil penelitian terbaru di bidang psikologi membuktikan bahwa IQ bukanlah satusatunya faktor yang mempengaruhi prestasi belajar seseorang, tetapi ada banyak faktor lain yang mempengaruhi diantaranya adalah faktor lingkungan, faktor biologis, dan faktor psikologis yang terdiri dari bakat, minat, dan kecerdasan emosi.

Kecerdasan emosi (EI) adalah sejumlah kemampuan dan keterampilan yang berkaitan dengan pembinaan hubungan sosial dengan lingkungan yang merujuk pada kemampuan mengenali perasaan diri sendiri dan orang lain, kemampuan memotivasi diri sendiri, dan kemampuan mengelola emosi dengan baik dan dalam hubungan dengan orang lain. Goleman, seorang peneliti dalam bidang kecerdasan emosi mengatakan bahwa kecerdasan emosi merupakan aspek psikologis yang sangat dominan dalam menentukan sukses dalam hidup ( 80\% ) ( Mangkunegara, 2010:93 ). Hal ini diakui bahwa mereka yang memiliki IQ rendah dan mengalami keterbelakangan mental akan mengalami kesulitan, bahkan mungkin tidak mampu mengikuti pendidikan formal yang seharusnya sesuai dengan usia mereka. Namun fenomena yang ada menunjukan bahwa tidak sedikit orang dengan IQ tinggi yang belajar rendah, dan ada banyak orang dengan IQ sedang yang dapat mengungguli prestasi belajar orang dengan IQ tinggi. Hal ini menunjukan bahwa IQ tidak selalu dapat memperkirakan prestasi belajar seseorang.

Prestasi belajar siswa tidak hanya dipengaruhi oleh motivasi tetapi juga dipengaruhi oleh Kecerdasan emosi. Terkadang suatu proses belajar tidak dapat mencapai hasil maksimal disebabkan karena ketiadaan kekuatan yang mendorong (motivasi), Motivasi dirumuskan sebagai suatu proses yang menentukan tingkatan kegiatan serta arah umum dari tingkah laku manusia, merupakan konsep yang berkaitan dengan konsep-konsep yang lain seperti minat, konsep diri, sikap dan sebagainya sehingga dapat mempengaruhi siswa yang dapat membangkitkan dan mengarahkan tingkah laku yang dimungkinkan untuk ditampilkan oleh para siswa. Salah satu indikator penilaian dari Prestasi belajar siswa dapat terlihat dari nilai ujian nasional. Berikut ini adalah Data Hasil Ujian Nasional SMA Swasta di Jakarta Barat sepanjang tahun ajaran 2017/2018 dan 2018/2019 :

Tabel 1. Data Hasil Ujian Nasional SMA Swasta di Jakarta Barat Tahun Ajaran 2017/2018 dan 2018/2019

\begin{tabular}{lcc}
\hline Data Hasil Ujian Nasional & $\mathbf{2 0 1 7 / 2 0 1 8}$ & $\mathbf{2 0 1 8 / 2 0 1 9}$ \\
\hline Klasifikasi & $\mathrm{B}$ & $\mathrm{C}$ \\
Rata Rata & 6,91 & 6,29 \\
Terendah & 5,10 & 5,07 \\
Tertinggi & 7,90 & 7,83 \\
Std .Deviasi & 3,40 & 4,30 \\
\hline
\end{tabular}

Sumber: Arsip Guru Bimbingan Konseling

Dari Tabel 1 diatas dapat diketahui bahwa hasil ujian nasional para siswa SMA Swasta di Jakarta Barat mengalami penurunan pada tahun ajaran 2018/2019 bila dibandingkan pada tahun ajaran 
Versi Online:

https://journal.ubm.ac.id/index.php/pengabdiandan-kewirausahaan

2Alabin/Peqdiriandimana pada tahun ajaran 2017/2018 kategori kelulusan para siswa berada pada kategori $\mathrm{B}$, sedangkan pada tahun ajaran 2018/2019 berada pada kategori C.

Dalam proses belajar mengajar motivasi sangat besar peranannya terhadap Prestasi belajar siswa belajar. Karena dengan adanya motivasi dapat menumbuhkan minat belajar siswa. Bagi siswa yang memiliki motivasi yang kuat akan mempunyai keinginan untuk melaksanakan kegiatan belajar mengajar. Sehingga boleh jadi siswa yang memiliki intelegensi yang cukup tinggi menjadi gagal karena kekurangan motivasi, sebab hasil belajar itu akan optimal bila terdapat motivasi yang tepat. Karenanya, bila siswa mengalami kegagalan dalam belajar, hal ini bukanlah semata-mata kesalahan siswa, tetapi mungkin saja guru tidak berhasil dalam membangkitkan motivasi siswa.

Selain motivasi, variabel lain yang ikut mempengaruhi tingkat Prestasi belajar siswa adalah Kecerdasan emosi, dimana Kecerdasan emosi tersebut merupakan sesuatu yang berkenaan dengan pengendalian diri seseorang terhadap bentuk-bentuk aturan. Seorang siswa perlu memiliki sikap Kecerdasan emosi dengan melakukan latihan yang memperkuat dirinya sendiri untuk selalu terbiasa patuh dan mempertinggi daya kendali diri.

Motivasi dan Kecerdasan emosi sangat berperan dalam meningkatkan Prestasi belajar siswa, dengan motivasi dan Kecerdasan emosi inilah siswa menjadi tekun dalam proses belajar mengajar, dan dengan motivasi dan Kecerdasan emosi itu pula kualitas hasil belajar siswa dapat diwujudkan dengan baik. Siswa yang dalam proses belajar mempunyai motivasi dan Kecerdasan emosi belajar yang kuat dan jelas akan tekun dan berhasil dalam belajarnya.
Jurnal Pengabdian dan Kewirausahaan Vol. 4 (No. 2) : no. 098 - no 111. Th. 2020

ISSN: 2581-2718

E-ISSN: 2620-3480

Tingginya motivasi dalam belajar

berhubungan dengan tingginya Prestasi belajar. Dengan dasar itulah penulis memilih SMA YP BDN sebagai objek penelitian yang mana di sekolah tersebut terdapat berbagai macam siswa yang memilki sifat dan karakter yang berbeda hal tersebut dapat dilihat dari Prestasi belajar masing-masing siswa tersebut.

Berikut ini di tampilkan data kenakalan / pelanggaran siswa SMA Swasta di Jakarta Barat antara tahun $2017-2019$ :

Tabel 2. Data Kenakalan / Pelanggaran Siswa SMA Swasta di Jakarta Barat Antara Tahun 2017 - 2019

\begin{tabular}{lcc}
\hline $\begin{array}{c}\text { Data Kenakalan / Pelanggaran } \\
\text { Siswa }\end{array}$ & $\mathbf{2 0 1 7 / 2 0 1 8}$ & $\mathbf{2 0 1 8 / 2 0 1 9}$ \\
\hline Tawuran & $0,0 \%$ & $0,0 \%$ \\
Merokok & $7,05 \%$ & $6,41 \%$ \\
Pencurian & $0 \%$ & $0 \%$ \\
Terlambat & $6,41 \%$ & $5,12 \%$ \\
Tidak Puasa Ramadhan & $7,05 \%$ & $3,84 \%$ \\
Tidak Sholat Berjamaah & $12,82 \%$ & $7,05 \%$ \\
Membolos & $6,41 \%$ & $3,84 \%$ \\
Meninggalkan Jam & $3,84 \%$ & $3,20 \%$ \\
Pelajaran Tanpa izin & $9,61 \%$ & $11,53 \%$ \\
Tidak melaksanakan & & \\
Remedial & $3,84 \%$ & $1,28 \%$ \\
Berbohong & $1,28 \%$ & $1,28 \%$ \\
Bersikap Kasar pada & & \\
Orang tua & & \\
\hline Sumber : LaDoran & & \\
\hline
\end{tabular}

Sumber : Laporan Tahunan SMA Swasta di Jakarta Barat

Dari tabel diatas dapat diketehui bahwa masih banyak pelanggaran yang dilakukan oleh para siswa/I siswa SMA Swasta di Jakarta Barat dalam kurun waktu 2017 - 2019, jika dilihat dari ratarata tingkat persentase pelanggaran yang dilakukan terdapat 3 pelanggaran dengan persentase tertinggi yaitu Tidak melaksanakan Remedial dengan rata-rata persentase adalah $10.6 \%$, yang kedua adalah Tidak Sholat Berjamaah dengan 
ratazirirataepersentase $9.9 \%$ dan yang ketiga belajar

adalah merokok dengan rata-rata persentase $6.7 \%$.

Manusia tumbuh dan berkembang dalam lingkungan. Lingkungan tidak dapat dipisahkan dalam kehidupan manusia. Lingkungan selalu mengitari manusia dari waktu ke waktu, sehingga antara manusia dan lingkungan terdapat hubungan timbal balik dimana lingkungan mempengaruhi manusia dan sebaliknya manusia juga mempengaruhi lingkungan. Begitu pula dalam proses belajar belajar mengajar, lingkungan merupakan sumber belajar yang berpengaruh dalam proses belajar dan perkembangan anak. Lingkungan sekolah adalah tempat berlangsungnya kegiatan belajar yang mendapatkan pengaruh dari luar terhadap keberlangsungan kegiatan tersebut. Lingkungan yang merupakan sumber belajar memiliki pengaruh dalam proses pembelajaran. Lingkungan dalam arti sempit adalah alam sekitar di luar diri individu atau manusia. Lingkungan itu mencakup segala material dan stimulus di dalam dan di luar individu, baik yang bersifat fisiologis, psikologis, maupun sosio-kultural (Dalyono, 2007: 129).

Berdasarkan uraian tersebut, maka penulis ingin meneliti lebih mendalam tentang Kecerdasan emosi, motivasi belajar, lingkungan sekolah dan Prestasi belajar Siswa SMA Swasta di Jakarta Barat. sehingga judul dari tesis ini "pengaruh kecerdasan emosi, lingkungan sekolah terhadap motivasi belajar dan dampaknya terhadap prestasi belajar siswa."

Berdasarkan latar belakang diatas maka hipotesis penelitian adalah sebagai berikut :

1) Kecerdasan emosi berpengaruh signifikan terhadap prestasi belajar.

2) Lingkungan sekolah berpengaruh

signifikan terhadap prestasi
3) Kecerdasan emosi berpengaruh signifikan terhadap Motivasi belajar.

4) Lingkungan sekolah berpengaruh signifikan terhadap Motivasi belajar

5) Motivasi belajar berpengaruh signifikan terhadap prestasi belajar

\section{METODE}

\section{Operasional Variabel Penelitian}

Berdasarkan tujuannya, penelitian ini merupakan penelitian eksplanatori yang Penelitian ini termasuk penelitian kausal komparatif yaitu penelitian dengan karakteristik masalah berupa hubungan sebab-akibat antara dua variabel atau lebih. Penelitian kausal komparatif merupakan penelitian ex post factor, yaitu tipe penelitian terhadap data yang dikumpulkan setelah terjadinya suatu fakta atau peristiwa (Indriantoro dan Supomo, 1999). Penelitian ini menggunakan pendekatan kuantitatif yang merupakan penekanan pada pengujian teori melalui pengukuran variabel penelitian dengan angka dan melakukan analisis data dengan prosedur statistik.

Variabel yang digunakan dalam penelitian ini terdiri dari 4 variabel yaitu kecerdasan emosi $\left(\mathrm{X}_{1}\right)$, Lingkungan sekolah $\left(\mathrm{X}_{2}\right)$ sebagai variabel bebas, Motivasi belajar $\left(\mathrm{X}_{3}\right)$ sebagai variabel mediasi dan Prestasi belajar (Y) sebagai variabel terikat. Setiap Variabel diukur menggunakan skala Likert (point 1 sampai dengan 5).

Pendekatan penelitian ini menggunakan metode SEM berbasis variance (Variance Based-SEM) disingkat VB-SEM dengan teknik Partial Least Square Path Modeling (PLS-PM).

PLS merupakan jenis analisis SEM yang berbasis komponen dengan sifat konstruk 
Versi Online:

https://journal.ubm.ac.id/index.php/pengabdiandan-kewirausahaan

forknatifielit奋hS pertama kali digunakan untuk mengolah data di economics sebagai alternatif teknik SEM dengan dasar teori yang lemah. PLS hanya berfungsi sebagai alat analisis predicator bukan uji model.

\section{Sampel dan Analisis Data}

Sampel penelitian adalah para siswa kelas XI dan XII SMA SWASTA DI JAKARTA BARAT tahun ajaran 2018/2019 yang berjumlah 89 orang. Teknik sampling yang digunakan adalah teknik sampling jenuh, yaitu teknik penentuan sampel bila semua anggota populasi digunakan sebagai sampel. Hal ini sering dilakukan bila jumlah populasi relatif kecil. Istilah lain sampel jenuh adalah sensus, dimana semua anggotapopulasi dijadikan sampel (Sugiyono, 2006).

Berikut tabel jumlah perhitungan dari sample yang akan digunakan dalam penelitian.

\section{HASIL DAN PEMBAHASAN}

\section{Gambaran Umum Responden}

Berdasarkan hasil penelitian yang dilakukan terhadap 89 responden, yaitu para Siswa/i pada SMA Swasta di Jakarta Barat. maka dapat diketahui gambaran umum mengenai jenis kelamin dan jurusan responden.

Untuk lebih jelasnya dibawah ini dikemukakan secara satu persatu gambaran umum responden penelitian

a. Jenis Kelamin

Tabel 3 Jenis Kelamin

\begin{tabular}{|l|l|c|c|}
\hline \multirow{3}{*}{ Valid } & & Frequency & Percent \\
\cline { 2 - 4 } & Laki-laki & 43 & $48,31 \%$ \\
\cline { 2 - 4 } & Perempuan & 46 & 51,69 \\
\cline { 2 - 4 } & Total & 89 & $100 \%$ \\
\hline
\end{tabular}

Dari tabel jenis kelamin diatas dapat diketahui bahwa jumlah responden untuk jenis kelamin Laki-laki adalah 43 orang
Jurnal Pengabdian dan Kewirausahaan Vol. 4 (No. 2) : no. 098 - no 111. Th. 2020

ISSN: 2581-2718

E-ISSN: 2620-3480

dan jenis kelamin perempuan berjumlah 46 orang.

b. Jurusan

Tabel 4 Jurusan

\begin{tabular}{|l|c|c|}
\hline & Frequency & Percent \\
\hline Kelas XI IPA & 21 & $23.60 \%$ \\
\hline Kelas XI IPS & 25 & $28.09 \%$ \\
\hline Kelas XII IPA & 17 & $19.10 \%$ \\
\hline Kelas XII IPS & 26 & $29.21 \%$ \\
\hline Total & 89 & $100 \%$ \\
\hline
\end{tabular}

Dari tabel status diatas dapat diketahui bahwa jumlah responden untuk Kelas XI IPA adalah 21 orang (23.60\%), Kelas XI IPS berjumlah 25 orang (28.09\%), Kelas XII IPA berjumlah 17 orang $(19.10 \%)$ dan Kelas XII IPS berjumlah 26 orang (29.21\%).

\section{Analisis Data Hasil Penelitian}

Adapun model pengukuran untuk uji validitas dan reabilitas, koefisiendeterminasi model dan koefisien jalur untuk model persamaan, dapat dilihat pada gambar berikut:

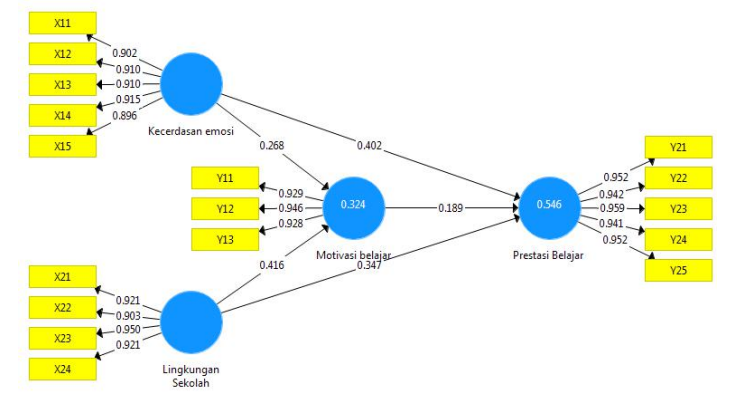

\section{Gambar 1 Hasil Uji Algoritma}

Uji yang dilakukan pada outer model adalah meliputi: Convergent Validity, Average Variance Extracted (AVE), Composite Reliability dan Cronbach's Alpha. Berdasarkan Gambar 1, hasil uji dapat dijelaskan sebagai berikut:

\section{Uji Validitas}

Pada tahap ini, pengujian dilakukan dengan menggunakan program SmartPLS versi 3.0. Dan uji validitas yang dilakukan adalah validitas konstruk. Pengujian 
Valigliparekenstruk dapat dilakukan dengan memperhatikan kuat tidaknya korelasi antara konstruk dan indikator pembentuk konstruk, serta hubungannya yang lemah dengan konstruk lainnya. Validitas konstruk terdiri dari dua bagian yaitu validitas konvergen dan validitas diskriminan.

\section{Convergent Validity}

Tabel 5 loading factor

\begin{tabular}{|c|c|c|c|}
\hline Variabel & Indikator & Nilai loading & Keterangan \\
\hline \multirow{5}{*}{$\begin{array}{l}\text { Kecerdasan } \\
\text { emosi }\end{array}$} & X11 & 0.902 & Valid \\
\hline & $\mathrm{X} 12$ & 0.910 & Valid \\
\hline & $\mathrm{X} 13$ & 0.910 & Valid \\
\hline & $\mathrm{X} 14$ & 0.915 & Valid \\
\hline & $\mathrm{X} 15$ & 0.896 & Valid \\
\hline \multirow{4}{*}{$\begin{array}{l}\text { Lingkungan } \\
\text { Sekolah }\end{array}$} & $\mathrm{X} 21$ & 0.921 & Valid \\
\hline & X22 & 0.903 & Valid \\
\hline & $\mathrm{X} 23$ & 0.950 & Valid \\
\hline & $\mathrm{X} 24$ & 0.921 & Valid \\
\hline \multirow{3}{*}{$\begin{array}{l}\text { Motivasi } \\
\text { belajar }\end{array}$} & Y11 & 0.929 & Valid \\
\hline & Y12 & 0.946 & Valid \\
\hline & Y13 & 0.928 & Valid \\
\hline \multirow{5}{*}{$\begin{array}{l}\text { Prestasi } \\
\text { Belajar }\end{array}$} & Y21 & 0.952 & Valid \\
\hline & Y22 & 0.942 & Valid \\
\hline & Y23 & 0.959 & Valid \\
\hline & Y24 & 0.941 & Valid \\
\hline & Y25 & 0.952 & Valid \\
\hline
\end{tabular}

Sumber: Olah data output SmartPLS

Validitas konvergen dapat dilihat dari loading factor untuk setiap indikator konstruk. Rule of thumb yang digunakan untuk menilai validitas konvergen yaitu nilai loading factor harus lebih besar dari 0,7 . Berdasarkan tabel 5 dapat diketahui bahwa semua nilai loading factor diatas 0.7 , sehingga dapat disimpukan bahwa seluruh indikator yang ada pada penelitian ini adalah valid.

Berdasarkan hasil perhitungan yang dijalankan oleh PLS Algorithm untuk indikator-indikator dalam tabel 5 diperoleh nilai AVE dan nilai kuadrat AVE seperti pada tabel 6 .

Tabel 6 Hasil Nilai Average Variance Extracted (AVE) dan Akar Kuadrat

AVE

\begin{tabular}{|l|c|c|}
\hline \multicolumn{1}{|c|}{ Variabel } & AVE & Akar AVE \\
\hline Kecerdasan emosi & 0.822 & 0.907 \\
\hline Lingkungan Sekolah & 0.854 & 0.924 \\
\hline Motivasi belajar & 0.874 & 0.935 \\
\hline Prestasi Belajar & 0.901 & 0.949 \\
\hline
\end{tabular}

Sumber: Hasil Pengolahan Data SmartPLS (2020)

Dari tabel 6 dapat dilihat bahwa nilai AVE untuk seluruh variabel memenuhi nilai syarat, yaitu di atas 0,5 . Nilai AVE terendah terdapat pada variabel Kecerdasan emosi dengan nilai 0.822. Dengan memperhatikan nilai loading factor pada tabel 5 dan nilai AVE pada tabel 6 maka data dari penelitian ini dapat dinyatakan telah memenuhi persyaratan uji validitas konvergen.

\section{b. Discriminant Validity}

Metode lain untuk menilai discriminant validity adalah dengan membandingkan nilai cross loadings untuk setiap konstruk dengan korelasi antara konstruk dengan konstruk lainnya dalam model. Model discriminant validity.

Tabel 7 Correlation Among laten variabel and cross loadings

\begin{tabular}{|c|c|c|c|c|}
\hline & $\begin{array}{c}\text { Kecerdasan } \\
\text { emosi }\end{array}$ & $\begin{array}{c}\text { Lingkungan } \\
\text { Sekolah }\end{array}$ & $\begin{array}{c}\text { Motivasi } \\
\text { belajar }\end{array}$ & $\begin{array}{c}\text { Prestasi } \\
\text { Belajar }\end{array}$ \\
\hline X11 & 0.902 & 0.344 & 0.365 & 0.572 \\
\hline X12 & 0.910 & 0.302 & 0.369 & 0.523 \\
\hline X13 & 0.910 & 0.362 & 0.338 & 0.619 \\
\hline X14 & 0.915 & 0.304 & 0.424 & 0.524 \\
\hline X15 & 0.896 & 0.281 & 0.387 & 0.483 \\
\hline X21 & 0.366 & 0.921 & 0.509 & 0.590 \\
\hline X22 & 0.292 & 0.903 & 0.511 & 0.522 \\
\hline X23 & 0.261 & 0.950 & 0.404 & 0.514 \\
\hline X24 & 0.375 & 0.921 & 0.452 & 0.528 \\
\hline Y11 & 0.398 & 0.511 & 0.929 & 0.525 \\
\hline Y12 & 0.359 & 0.479 & 0.946 & 0.507 \\
\hline Y13 & 0.407 & 0.438 & 0.928 & 0.458 \\
\hline Y21 & 0.584 & 0.568 & 0.512 & 0.952 \\
\hline
\end{tabular}


Versi Online:

https://journal.ubm.ac.id/index.php/pengabdiandan-kewirausahaan

\begin{tabular}{|c|c|c|c|c|}
\hline & $\begin{array}{c}\text { Kecerdasan } \\
\text { emosi }\end{array}$ & $\begin{array}{c}\text { Lingkungan } \\
\text { Sekolah }\end{array}$ & $\begin{array}{c}\text { Motivasi } \\
\text { belajar }\end{array}$ & $\begin{array}{c}\text { Prestasi } \\
\text { Belajar }\end{array}$ \\
\hline Y22 & 0.536 & 0.533 & 0.493 & 0.942 \\
\hline Y23 & 0.591 & 0.521 & 0.541 & 0.959 \\
\hline Y24 & 0.552 & 0.593 & 0.528 & 0.941 \\
\hline Y25 & 0.594 & 0.561 & 0.453 & 0.952 \\
\hline
\end{tabular}

Sumber: Olah data output smartPLS

Dari tabel 7 menunjukkan bahwa nilai cross loading dari masing-masing item terhadap konstruk nya lebih besar dari pada nilai loading dengan konstruk yang lain. Dari hasil tersebut dapat disimpulkan bahwa tidak terdapat permasalahan pada discriminant validity.

\section{Uji Reliabilitas}

\section{Composite Reliability (CR)}

Setelah menguji validitas konstruk, pengujian selanjutnya adalah uji reliabilitas konstruk yang diukur dengan dua kriteria yaitu Composite Reliability (CR) dan Cronbach's Alpha (CA) dari blok indikator yang mengukur konstruk CR digunakan untuk menampilkan reliabilitas yang baik. Suatu konstruk dinyatakan reliabel jika nilai composite reliabilty maupun Cronbach's Alpha $>0.7$

Tabel 8 Laten variabel coefficients

\begin{tabular}{|c|c|c|c|c|}
\hline & $\begin{array}{c}\text { Kecerdasa } \\
\text { n emosi }\end{array}$ & $\begin{array}{c}\text { Lingkunga } \\
\text { n Sekolah }\end{array}$ & $\begin{array}{c}\text { Motiva } \\
\text { si } \\
\text { belajar }\end{array}$ & $\begin{array}{c}\text { Presta } \\
\text { si } \\
\text { Belaja } \\
\mathbf{r}\end{array}$ \\
\hline $\begin{array}{c}\text { Composit } \\
\boldsymbol{e} \\
\text { Reliability }\end{array}$ & 0.958 & 0.959 & 0.954 & 0.978 \\
\hline $\begin{array}{c}\text { Cronbach } \\
\text { s Alpha }\end{array}$ & 0.946 & 0.943 & 0.928 & 0.972 \\
\hline
\end{tabular}

Sumber: Olah data Output SmartPLS

Berdasarkan tabel 4.11 bahwa hasil pengujian composite reliability dan Cronbach alpha menunjukan nilai $>0.7$

yang artinya nilai pada tiap instrumen reliabel.

\section{Structural Model (Inner Model)}

Setelah melakukan evaluasi model dan diperoleh bahwa setiap konstruk telah memenuhi syarat Covergent Valdity, Discriminant Validity, dan Composite Reliability, maka yang berikutnya adalah
Jurnal Pengabdian dan Kewirausahaan Vol. 4 (No. 2) : no. 098 - no 111. Th. 2020

ISSN: 2581-2718

E-ISSN: 2620-3480

evaluasi model structural yang meliputi

pengujian path coefficient, dan $\mathrm{R}^{2}$.

Inner model (inner relation, structural model, dan substantive theory) menggambarkan hubungan antara variabel laten berdasarkan pada teori substantif. Model structural di evaluasi dengan menggunakan R-square untuk konstruk dependen, Stone-Geiser Qsquare test untuk predictive relevan. Nilai $\mathrm{R}^{2}$ dapat digunakan untuk menilai pengaruh variabel laten independen tertentu, variabel laten dependen apakah mempunyai pengaruh substantive (Ghozali, 2014). Semakin tinggi nilai $\mathrm{R}^{2}$ maka semakin besar kemampuan variabel laten indipenden dapat menjelaskan variabel laten dependen. Hasil $\mathrm{R}^{2}$ sebesar $0.67,0.33$, dan 0.19 mengindikasi bahwa model "baik", "moderat", dan "lemah" (Ghozali, 2014).

Tabel 9 R-squared coefficients

\begin{tabular}{|l|c|}
\hline \multicolumn{1}{|c|}{ Variabel } & $\boldsymbol{R}$ - Square \\
\hline Motivasi belajar & 0.324 \\
\hline Prestasi belajar & 0.546 \\
\hline
\end{tabular}

Sumber: Olah data output SmartPLS

Berdasarkan Tabel 9 diperoleh nilai R-Square untuk variabel Motivasi belajar sebesar 0.324 hal ini berarti 32,4\% variasi atau perubahan Motivasi belajar dipengaruhi oleh Kecerdasan emosi dan Lingkungan Sekolah, sedangkan sisanya sebanyak $67.6 \%$ dijelaskan oleh sebab lain. Berdasarkan hal tersebut maka hasil perhitungan $\mathrm{R}^{2}$ menunjukkan bahwa $\mathrm{R}^{2}$ termasuk lemah.

Berdasarkan Tabel 9 diperoleh nilai R-Square untuk variabel Prestasi Belajar sebesar 0.546 hal ini berarti $54,6 \%$ variasi atau perubahan Prestasi Belajar dipengaruhi oleh Kecerdasan emosi, Lingkungan Sekolah dan Motivasi belajar, sedangkan sisanya sebanyak $45.4 \%$ dijelaskan oleh sebab lain. Berdasarkan hal tersebut maka hasil perhitungan $\mathrm{R}^{2}$ menunjukkan bahwa $\mathrm{R}^{2}$ termasuk moderat. 
Versi Online:

https://journal.ubm.ac.id/index.php/pengabdiandan-kewirausahaan

Hasil Pendissamping melihat nilai R-square, model juga dievaluasi dengan melihat Qsquare prediktif relevansi untuk model konstruktif. Q-square mengukur seberapa baik nilai observasi dihasilkan oleh model dan juga estimasi parameternya. Besaran $\mathrm{Q}^{2}$ memiliki nilai rentang $0<\mathrm{Q}^{2}<1$, dimana semakin mendekati 1 berarti model semakin baik. Besaran $\mathrm{Q}^{2}$ ini setara dengan koefisien determinasi total pada analisis jalur path (path analysis). Nilai $\mathrm{Q}^{2}>0$ menunjukan model memilki prediktif relevansi, sebaliknya jika nilai $\mathrm{Q}^{2} \leq 0$ menunjukan model kurang memiliki prediktif relevansi.

$$
\begin{aligned}
\text { Q-Square } & =1-[(1-\mathrm{R} 21) \times(1-\mathrm{R} 22)] \\
& =1-[1-0.324) \times(1-0.546)] \\
& =1-(0.676 \times 0.454) \\
& =1-0.307 \\
& =0.693
\end{aligned}
$$

Berdasarkan hasil perhitungan di atas, diketahui nilai Q-Square sebesar 0.693. Hal ini menunjukkan bahwa besarnya keragaman data penelitian yang dapat dijelaskan dari penelitian ini adalah sebesar $69.3 \%$ dan sebesar $30.7 \%$ sisanya dijelaskan oleh faktor lain di luar penelitian ini.

\section{Hasil Bootstrapping}

Dalam PLS, pengujian setiap hubungan dilakukan dengan menggunakan simulasi dengan metode bootstrapping terhadap sampel. Pengujian ini bertujuan untuk meminimalkan masalah ketidak normalan dalam penelitian. Hasil pengujian dengan

metode bootstrapping dari PLS sebagai berikut:

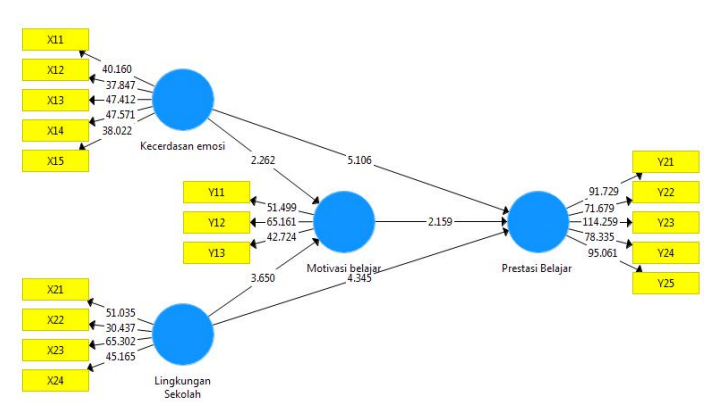

Gambar 2 Diagram Path
Jurnal Pengabdian dan Kewirausahaan Vol. 4 (No. 2) : no. 098 - no 111. Th. 2020

ISSN: 2581-2718

Sumber: Olah data output SmartPLS

Sementara itu untuk hasil perhitungannya dapat dilihat berdasarkan pengaruh langsung dibawah ini.

Tabel 10. Pengaruh Langsung

\begin{tabular}{|l|r|r|r|}
\hline & $\begin{array}{c}\text { Original } \\
\text { Sample (O) }\end{array}$ & $\begin{array}{c}\text { T Statistics } \\
(\mid \mathbf{O} / \text { STDEV|) }\end{array}$ & P Values \\
\hline KE -> MB & 0.268 & 2.262 & 0.024 \\
\hline KE -> PB & 0.402 & 5.106 & 0.000 \\
\hline LS -> MB & 0.416 & 3.650 & 0.000 \\
\hline LS -> PB & 0.347 & 4.345 & 0.000 \\
\hline MB -> PB & 0.189 & 2.159 & 0.031 \\
\hline
\end{tabular}

Sumber: Olah data output SmartPLS

Berdasarkan tabel 10 menunjukkan hasil perhitungan PLS yang menyatakan pengaruh langsung antar variabel. Dikatakan ada pengaruh langsung jika nilai T Statistics $>1.96$ dan dikatakan tidak ada pengaruh jika $\mathrm{T}$ Statistics $<1.96$.

Berdasarkan tabel 4.6 maka dapat dinyatakan sebagai berikut:

1. Variabel Kecerdasan emosi berpengaruh signifikan terhadap variabel Motivasi belajar dengan nilai $\mathrm{T}$ Statistics $>1.96$.

2. Variabel Kecerdasan emosi berpengaruh signifikan terhadap variabel Prestasi belajar dengan nilai $\mathrm{T}$ Statistics $>1.96$.

3. Variabel Lingkungan Sekolah berpengaruh signifikan terhadap variabel Motivasi belajar dengan nilai $\mathrm{T}$ Statistics $>1.96$.

4. Variabel Lingkungan Sekolah berpengaruh signifikan terhadap variabel Prestasi 
$\frac{\text { Hasil Penelitiaelajar dengan nilai } \mathrm{T}}{\text { Statistics }>1.96 .}$

5. Variabel Motivasi belajar berpengaruh signifikan terhadap variabel Prestasi belajar dengan nilai $\mathrm{T}$ Statistics $>1.96$.

\section{Pengujian Hipotesis}

Pengujian Hipotesis dilakukan dengan melihat nilai probabilitas dan tstatistik nya. Untuk nilai probabilitas, Nilai t-tabel untuk alpha 5\% adalah 1,96. Sehingga kriteria penerimaan Hipotesa adalah ketika t-statistik > t-tabel. Pengujian ini dimaksudkan untuk menguji hipotesis yang terdiri dari 5 hipotesis berikut ini:

\section{Uji Hipotesis 1}

$\mathrm{H}_{1}$ : Kecerdasan emosi berpengaruh signifikan terhadap Motivasi belajar Berdasarkan tabel 10 dengan nilai $\mathrm{T}$ - statistics 2.262 yang berarti > 1.96 maka $\mathrm{H}_{1}$ diterima, yang berati bahwa Kecerdasan emosi memiliki pengaruh positif dan signifikan terhadap Motivasi belajar, artinya perubahan nilai Kecerdasan emosi mempunyai pengaruh searah terhadap perubahan Motivasi belajar atau dengan kata lain apabila Kecerdasan emosi meningkat, maka akan terjadi peningkatan

pada Motivasi belajar dan secara statistik memiliki pengaruh yang signifikan. Berdasarkan hasil pengolahan data dengan SmartPLS versi 3.0 diketahui bahwa nilai koefisien jalur Kecerdasan emosi terhadap Motivasi belajar sebesar 0.268 , yang berarti bahwa jalur Kecerdasan emosi memiliki hubungan positif terhadap Motivasi belajar dengan derajat tingkat keeratan hubungan yang lemah.
ISSN: 2581-2718

2. Uji Hipotesis 2

E-ISSN: 2620-3480

$\mathrm{H}_{2}:$ Kecerdasan $\begin{array}{r}\text { emosi } \\ \text { berpengaruh } \\ \text { terhadap Prestasi Belajar. }\end{array}$

Berdasarkan tabel 10 dengan nilai $\mathrm{T}$ - statistics 5.106 yang berarti > 1.96 maka $\mathrm{H}_{2}$ diterima, yang berati bahwa Kecerdasan emosi memiliki pengaruh positif dan signifikan terhadap Prestasi Belajar, artinya perubahan nilai Kecerdasan emosi mempunyai pengaruh searah terhadap perubahan Prestasi Belajar atau dengan kata lain apabila Kecerdasan emosi meningkat, maka akan terjadi peningkatan pada Prestasi Belajar dan secara statistik memiliki pengaruh yang signifikan. Berdasarkan hasil pengolahan data dengan SmartPLS versi 3.0 diketahui bahwa nilai koefisien jalur Kecerdasan emosi terhadap Prestasi Belajar sebesar 0.402, yang berarti bahwa jalur Kecerdasan emosi memiliki hubungan positif terhadap Prestasi Belajar dengan derajat tingkat keeratan hubungan yang moderat.

3. Uji Hipotesis 3

$\mathrm{H}_{3}$ : Lingkungan $\begin{array}{r}\text { Sekolah } \\ \text { berpengaruh }\end{array}$
terhadap Motivasi belajar.

Berdasarkan tabel 10 dengan nilai $\mathrm{T}$ - statistics 3.650 yang berarti $>$ 1.96 maka $\mathrm{H}_{3}$ diterima, yang berati bahwa Lingkungan Sekolahmemiliki pengaruh positif dan signifikan terhadap Motivasi belajar, artinya perubahan nilai Lingkungan Sekolah mempunyai pengaruh searah terhadap perubahan Motivasi belajar atau dengan kata lain apabila Lingkungan Sekolah meningkat, maka akan terjadi peningkatan pada Motivasi belajar dan secara statistik memiliki pengaruh yang signifikan. Berdasarkan hasil 


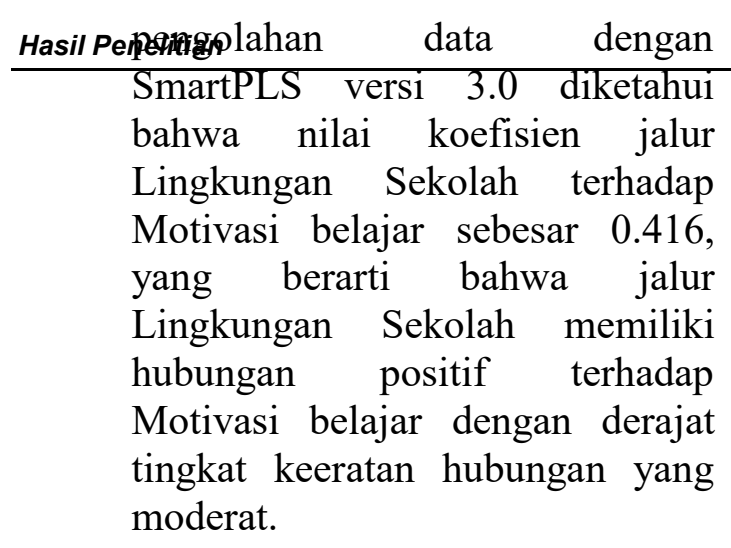

4. Uji Hipotesis 4

$\mathbf{H}_{4}$ : Lingkungan $\begin{array}{r}\text { Sekolah } \\ \text { berpengaruh } \\ \text { terhadap Prestasi Belajar. }\end{array}$

Berdasarkan tabel 10 dengan nilai $\mathrm{T}$ - statistics 4.345 yang berarti $>$ 1.96 maka $\mathrm{H}_{4}$ diterima, yang berati bahwa Lingkungan Sekolah memiliki pengaruh positif dan signifikan terhadap Prestasi Belajar, artinya perubahan nilai Lingkungan Sekolah mempunyai pengaruh searah terhadap perubahan Prestasi Belajar atau dengan kata lain apabila Lingkungan Sekolah meningkat, maka akan terjadi peningkatan pada Prestasi Belajar dan secara statistik memiliki pengaruh yang signifikan. Berdasarkan hasil pengolahan data dengan SmartPLS versi 3.0 diketahui bahwa nilai koefisien jalur Lingkungan Sekolah terhadap Prestasi Belajar sebesar 0.347, yang berarti bahwa jalur Lingkungan Sekolah memiliki hubungan positif terhadap Prestasi Belajar dengan derajat tingkat keeratan hubungan yang moderat.

5. Uji Hipotesis 5

H5: Motivasi relajar
berpengaruh
terhadap Prestasi Belajar.

Berdasarkan tabel 11 dengan nilai $\mathrm{T}$ - statistics 2.159 yang berarti $>$ 1.96 maka $\mathrm{H}_{5}$ diterima, yang berati bahwa Motivasi belajar memiliki pengaruh positif dan
ISSN: 2581-2718

signifikan Prestasi Belajar, 2620-3480 perubahan nilai Motivasi belajar mempunyai pengaruh searah terhadap perubahan Prestasi Belajar atau dengan kata lain apabila Motivasi belajar meningkat, maka akan terjadi peningkatan pada Prestasi Belajar dan secara statistik memiliki pengaruh yang signifikan. Berdasarkan hasil pengolahan data dengan SmartPLS versi 3.0 diketahui bahwa nilai koefisien jalur Motivasi belajarterhadap Prestasi Belajar sebesar 0.189, yang berarti bahwa jalur Motivasi belajar memiliki hubungan positif terhadap Prestasi Belajar dengan derajat tingkat keeratan hubungan yang lemah.

\section{KESIMPULAN}

1. Kecerdasan emosi berpengaruh positif dan signifikan terhadap motivasi belajar artinya perubahan nilai Kecerdasan emosi mempunyai pengaruh searah terhadap perubahan motivasi belajar atau dengan kata lain apabila Kecerdasan emosi baik maka akan terjadi peningkatan motivasi belajar dan secara statistik memiliki pengaruh yang signifikan.

2. Kecerdasan emosi berpengaruh positif dan signifikan terhadap prestasi belajar artinya perubahan nilai Kecerdasan emosi mempunyai pengaruh searah terhadap perubahan prestasi belajar atau dengan kata lain apabila Kecerdasan emosi baik maka akan terjadi peningkatan prestasi belajar dan secara statistik memiliki pengaruh yang signifikan.

3. Lingkungan sekolah berpengaruh positif dan signifikan terhadap motivasi belajar artinya perubahan nilai Lingkungan sekolah 
Hasil Pemanyai pengaruh searah

terhadap perubahan motivas

belajar atau dengan kata lain apabila Lingkungan sekolah baik maka akan terjadi peningkatan pada motivasi dan secara statistik memiliki pengaruh yang signifikan.

4. Lingkungan sekolah berpengaruh positif dan signifikan terhadap prestasi belajar artinya perubahan nilai Lingkungan sekolah mempunyai pengaruh searah terhadap perubahan prestasi belajar atau dengan kata lain apabila Lingkungan sekolah baik maka akan terjadi peningkatan pada prestasi belajar dan secara statistik memiliki pengaruh yang signifikan.

5. Motivasi belajar berpengaruh positif dan signifikan terhadap prestasi belajar artinya perubahan nilai Motivasi belajar mempunyai pengaruh searah terhadap perubahan prestasi belajar atau dengan kata lain apabila Motivasi belajar meningkat maka akan terjadi peningkatan pada prestasi belajar dan secara statistik memiliki pengaruh yang signifikan.

\section{SARAN}

1. Diharapkan para Siswa dapat mengatur kehidupan emosinya dengan inteligensi, menjaga keselarasan emosi dan pengungkapannya melalui keterampilan kesadaran diri, pengendalian diri, motivasi diri, empati dan keterampilan sosial. Karena kecerdasan emosional merupakan salah satu faktor yang penting yang seharusnya dimiliki oleh para Siswa yang memiliki kebutuhan untuk meraih prestasi belajar yang lebih baik. dimensi yang paling kuat hubungannya adalah dimensi Kesadaran diri terhadap dimensi Prestasi belajar.

kesadaran diri merupakan upaya perwujudan jati diri pribadi. Seseorang dapat disebut sebagai pribadi yang berjati diri tatkala dalam pribadi orang yang bersangkutan tercermin penampilan, rasa, cipta, dan karsa; sistem nilai (value system), cara pandang (attitude), dan perilaku (behavior) yang dimiliki. Kesadaran diri siswa dapat dibangun dengan belajar memahami tipe karakter pribadi, pikiran dan perasaan yang ada, minat dan bakat yang dimiliki. Mengembangkan sikap kesadaran, penerimaan dan rasa menghargai diri sendiri. Menyadari kelebihan dan kekurangan yang dimiliki dengan membangun sikap introspeksi dan learning attitude yang positif.

2. Perlu adanya penanaman Motivasi belajar pada para Siswa sejak dini melalui dibangunnya hubungan yang akrab dan bersahabat antara pihak sekolah dengan para Siswa/i, sehingga para Siswa dapat menunjukan adanya keinginan, harapan, penentuan untuk mencapai sesuatu hasil yang dinyatakan secara eksplisit. Siswa perlu memahami dan mengenal diri sendiri termasuk juga memahami dan mengembangkan gaya belajar yang dimilikinya. Upaya Siswa dalam mengembangkan gaya belajar dan Motivasi belajar dilakukan dengan : mengembangkan pemahaman perlunya motivasi dalam usaha mencapai suatu tujuan hidup, mengembangkan motivasi belajar dalam upaya mencapai keberhasilan belajar dan mengembangkan Motivasi belajar dan disiplin belajar dalam mencapai prestasi akademik. 

untuk lebih agresif lagi melakukan upaya yang konkrit dalam melengkapi segala fasilitas di Lingkungan sekolah. Dalam suatu sekolah untuk mencapai suatu tujuan pendidikan diperlukan alat pendukung yang digunakan dalam proses atau aktifitas belajar mengajar. Lingkungan sekolah perlu diperbaiki, dalam arti Lingkungan sekolah yang baik dapat mendukung pelaksanaan pembelajaran seperti lengkapnya alat-alat laboratorium, ruangan yang bersih, ventilasi yang cukup, peralatan dapat berfungsi dengan baik, hubungan yang serasi antara seorang siswa dengan siswa lain dan juga dengan para guru, penerangan yang cukup, prosedur dan tata kerja yang jelas ikut menyebabkan prestasi belajar para siswa meningkat. dimensi yang paling kuat hubungannya adalah dimensi Kebersihan Lingkungan sekolah terhadap dimensi Prestasi belajar pada prestasi belajar. Cara - cara yang perlu dilakukan untuk memelihara lingkungan sekolah antara lain sebagai berikut: Menyusun dan memasyarakatkan perogram sekolah hijau, menginvestasikan dan melaksanakan perogram sekolah hijau, Melaksanakan tata tertib kebersihan dan kelestarian lingkungan sekolah, Mengembangkan kecintaan dan kepedulian siswa terhadap lingkungan sekolah melalui berbagai lomba peduli lingkungan, seperti lomba kebersihan antar kelas, menulis, menggambar, atau aneka kreativitas lain yang bersifat ramah lingkungan, Mengadakan pengawasan dan penegakan kedisiplinan, Mengadakan gerakan cinta kebersihan dan kesehatan lingkungan sekolah dan memanfaatkan hari-hari besar nasional untuk gerak peduli lingkungan

4. Dalam penelitian ini, peneliti hanya melihat pengaruh masingmasing variabel terikat dengan prestasi belajar. Ada baiknya untuk penelitian selanjutnya dilihat pula pengaruh antar variabel-variabel terikat.

\section{DAFTAR PUSTAKA}

Arikunto, Suharsimi. (2004). Prosedur Penelitian: Suatu pendekatan Praktek. Bandung: Rineka Cipta.

Arikunto, Suharsimi. (1993). Prosedur Penelitian, Suatu Pendekatan Praktek, Edisi Kesembilan, Rineka Cipta, Jakarta.

Ayres, dkk (2005). Factors related to motivation to learn and motivation to transfer learning in a nursing population. North Carolina State University, ProQuest, UMI Dissertations Publishing.

Badriyah, (2012). Pengaruh Kecerdasan emosi dan motivasi belajar terhadap prestasi belajar Matematika Siswa Kelas XI SMA Negeri Bangsri Tahun ajaran 2011/2011.

Ballard \& Clanchy,John. (1990). Study Abroad Manual for Asian Students, Selangor Darul Ehsan: Longman Malaysia .

Biggs,John B. (1991).The Role of learning Study Process, British: Journal of Educational Psychogy.

Cece Wijaya, dkk (1993). Upaya pembaharuan dalam pendidikan dan pengajaran, Bandung. PT. Remaja Rosda Karya.

Djaali. (2011). Psikologi Pendidikan. Jakarta:Bumi Aksara.

Hamzah B Uno. (2011). Teori Motivasi dan Pengukurannya. Jakarta: Bumi Aksara. 
Sistem E-Learning. Tesis (Tidak diterbitkan). Yogyakarta:

Fakultas Psikologi Universitas Gadjah Mada.

Jenkins, dkk (2006). Emotional intelligence of faculty members, the learning Teachers College, Columbia University, ProQuest, UMI Dissertations

Publishing.environment, and empowerment of baccalaureate nursing students.

Johnson, dkk (2012). Urban Students' Perceptions of the School Environment's Influence on School Violence. Children \& Schools 34.2 (Apr 2012): 92-102

Joko Sumarno, (2008). Minimalisasi pelanggaran disiplin sekolah melalui efektivitas Tim kedisplinan, Vol. 5, No. 2

Kusharyanti , Dkk (2012). Pengaruh Kompetensi Profesional Guru Dan Iklim Sekolah Terhadap Prestasi Belajar Siswa

Landau, dkk (2001). Development of students' emotional intelligence: participative classroom environments in higher education. Academy of Educational Leadership Journal15.3(2011): 89-104.

M. Ngalim Purwanto, (1998) Psikologi Pendidikan, Jakarta: PT Remaja Rosdakarya.

Maftukhah, (2006). Pengaruh Kondisi Sosial Ekonomi Orang Tua Terhadap Prestasi Belajar Geografi Siswa Kelas VIII SMP N 1 Randudongkal Kabupaten Pemalang

Mahyuddi, dkk, (2012). Emotional Intelligence, Achievement Motivation and Academic Achievement Among Students of the Public and Private Higher Institutions. Remaja Rosdakarya.

Muhibbin Syah. (2003). Psikologi Pendidikan Dengan Pendekatan Baru. Bandung: PT Remaja Rosda Karya.Oemar Hamalik. (2009). Proses Belajar Mengajar. Jakarta: Bumi Aksara.

Mu'tadin, Z. (2002). Pengantar Pendidikan dan Ilmu Perilaku Kesehatan. Yogyakarta. Andi Offset

Nurmalia Erlina, (2011). Pengaruh fasilitas sekolah dan lingkungan belajar terhadap prestasi belajar di MAN Malang 1.

Puspitasari, (2007). Hubungan antara selfesteem, kecerdasan emosi dan motivasi belajar dengan prestasi belajar siswa kelas akselerasi di SMA Negri 1 Blitar.

Reber, Arthur. S. (1988). The Pinguin Dictionary of Psychology. Ringwood Victoria : Penguin Books Australia. Ltd.

Riyanto Agus, (2007). Pengaruh kecerdasan emosional (EQ) dan kecerdasan spiritual (SQ) terhadap prestasi belajar mata diklat ekonomi siswa kelas I SMK Negeri 1 Malang.

Saputro, (2007). Pengaruh motivasi dan Lingkungan Sekolah terhadap prestasi belajar pelajar siswa kelas XI SMA negri 12 Semarang tahun ajaran 2005/2006

Sardiman. A.M. (2009). Interaksi dan Motivasi Belajar-Mengajar. Jakarta: PT Raja Grafindo Persada.

Saroni, Muhammad, 2006. Manajemen Sekolah, Jogjakarta: Ar-Ruzz.

Slameto. (2010). Belajar dan FaktorFaktor Yang Mempengaruhi. Jakarta: PT.Rineka Cipta.

Sue Campbell Clark, dkk (2003). Undergraduate management skills courses and students' 
Versi Online:

https://journal.ubm.ac.id/index.php/pengabdiandan-kewirausahaan

Hasil Peneftingtional intelligence. Journal of Management Education 27.1

Sugiyono, (2006). Metode Penelitian Bisnis. Bandung : Alfa beta.

Sumadi, Suryabrata. 1998. Metodologi Penelitian. Cetakan sebelas. Jakarta : PT RajaGrafindo Persada.

Wahidin, (2001). Hubungan antara Kecerdasan Emosi dan Motivasi Belajar dengan Prestasi Belajar Siswa.

Wicaksono Pekik, (2011). Pengaruh Fasilitas Belajar, Motivasi Belajar dan Minat Belajar terhadap Prestasi Belajar Siswa kelas X SMK Muhammadiyah Prambanan tahun pelajaran $2011 / 2012$

Widyaningrum Shinta (2010). Implementasi Model Learning Starts With A Question untuk Meningkatkan Prestasi Belajar Materi Sejarah di Kelas VII B SMP Negeri I Sleman Tahun Ajaran 2010/2011.

Winkel, WS. (1997). Psikologi Pendidikan dan Evaluasi Belajar. Jakarta : Gramedia. 